\title{
ANALISA COST SHARING PERHITUNGAN TARIF HEMODIALISIS (HD) MASYARAKAT MISKIN DI RUMAH SAKIT UMUM PKU MUHAMMADIYAH UNIT I YOGYAKARTA
}

\author{
Primadinta, Triyani Marwati, Solikhah \\ Fakultas Kesehatan Masyarakat, Universitas Ahmad Dahlan, Yogyakarta
}

\begin{abstract}
Background: Growing and expanding hopital may be efficiently and effectively managed, it is requiredto be conducted to face the tight competition in world of health service. If the hospital wish to survive in the competition, they need to recount the existing hospital tariff previously, that is by using competitive tariff model calculation. Hospital of PKU Muhammadiyah Unit I Yogyakarta divides $\mathrm{HD}$ tariff into two parts, these are Single Use and Re Use tariff. There are cost sharing differences between HD tariff in hospital and government. In this research, the reseacher only focuses on HD tariff of $\mathrm{Re}$ Use in order to reduce cost sharing. All this time, the hospital has never counted different cost. It can create lose for the hospital. th s researcher interest to analyze the cost sharing of hemodialisis tariff calculation for poor in public hospital of PKU Muhammadiyah Unit I Yogyakarta. Methode: This research type is descriptive research qualitative which analyzed real expense by using real cost methode and difference which is burdened by patien toward real tariff, meanwhile opinion about cost sharing is taken by interview with superintendent finance and superintendent of hemodialisis unit using interview method.

Resulth: this research show the real tariff equal to Rp.912.571 while tariff released by hospital equal to Rp.575.000, and difference between second tariff is Rp.337.751, while tariff given by government is Rp.528.067 and difference with the real tariff equal to Rp.384.684.

Conclusion: that unit based cost tariff higher than tariff given by hospital at this time, the biggest expense is component for examines or substance used up wear. The hospital should determine the strategy to decrease the difference.
\end{abstract}

Key Words: cost sharing, real cost method, tariff packet, hemodialisis, poor, society.

\section{PENDAHULUAN}

Rumah sakit merupakan sebuah lembaga usaha yang padat karya yang multi disiplin, padat modal, padat teknologi, padat ilmu, padat sistem, padat tenaga, serta dipengaruhi oleh lingkungan yang selalu berubah. Sebuah rumah sakit harus bisa bertahan bahkan berkembang dengan mengikuti perkembangan kebutuhan masyarakat saat ini. Langkah yang dilakukan untuk tetap bisa bertahan dan berkembang, tentu memerlukan dana yang tidak sedikit. Penentuan tarif yang efisien dan efektiflah yang sangat diperlukan disini.

Rumah sakit yang tumbuh dan berkembang tentunya dikelola secara efisien dan efektif, hal tersebut perlu dilakukan untuk mengadapi persaingan ketat dalam dunia kesehatan. Rumah sakit bisa survive dalam menjalani competisi yang ada, tentunya pihak rumah sakit harus menghitung kembali tarif rumah sakit yang ada sebelumnya, yaitu untuk meminimalisir perhitungan tarif yang begitu tinggi dengan menggunakan model perhitungan tarif yang competitive, walaupun dengan tarif rendah tetapi tetap menjunjung tinggi suatu kualitas untuk bisa menjalankan visi dan misi sebuah rumah sakit, sehingga rumah sakit tidak mengalami kerugian dalam hal tarif maupun 
customer. Hal tersebut dilakukan untuk menarik minat kembali pasien lama dan pasien baru dalam memanfaatkan pelayanan yang ada.

Efisiensi biaya dari sisi demand adalah memberlakukan iuran biaya (cost sharing). Motivasi dibalik penerapan iuran biaya adalah asumsi bahwa demand yang tinggi atas layanan kesehatan merupakan penyebab utama tingginya biaya kesehatan. Tingkat pendidikan dan pengetahuan yang meningkat dan akses informasi yang meluas menyebabkan masyarakat sadar akan pentingnya kesehatan. Tersedianya perlindungan Jamkesmas dan tanpa / sedikit resiko keuangan, besar kemungkinan terjadinya moral hazard, penggunaan jasa yang tidak dibutuhkan dan tidak tepat. ${ }^{1}$ Tujuan iuran biaya adalah agar masyarakat bertindak rasional dan terhindar dari moral hazard. Namun, iuran biaya yang melampaui batas kemampuan peserta dapat menjadi paradok dari prinsip askes yang memproteksi penduduk dari kerugian keuangan dan sekaligus menurunkan akses peserta. ${ }^{2}$

Adapun program yang menjadi tanggung jawab pemerintah, yaitu: a) program yang tergolong sebagai public goods, dan b) program pemeliharaan kesehatan bagi penduduk miskin. ${ }^{3}$ Badan Pusat Statistik (BPS) mencatat jumlah penduduk miskin pada 2008 sebanyak 35 juta jiwa. Garis kemiskinan dengan pengeluaran Rp.182.636/ orang/bulan. Dana penanggulangan kemiskinan 2009 Rp 70 triliun. ${ }^{4}$

Angka harapan hidup orang Indonesia saat ini hanya 67,8 tahun. ${ }^{5}$ Pada usia yang seperti ini, manusia rentan terhadap berbagai macam jenis penyakit berat, hal ini dikarenakan fungsi dari organ tubuh manusia sudah mulai menurun, sehingga organ tubuh tidak dapat berfungsi dengan semestinya. Semakin tua seseorang maka semakin banyak jenis penyakit yang dimiliki, diantaranya adalah penyakit gagal ginjal. Salah satu penyakit degeneratif yang harus memerlukan dana besar untuk bisa bertahan hidup.

Ginjal adalah salah satu organ yang sangat penting dalam tubuh manusia, karena ginjal akan menyaring semua racun dan membuang kotoran, jika kinerja ginjal terlalu keras maka kesehatan ginjal akan menurun, hal ini yang bisa mengakibatkan seseorang harus menjalani cuci darah. Cuci darah adalah tindakan medis yang dilakukan dengan menggunakan mesin cuci darah atau biasa disebut hemodialisis (mesin HD), mesin cuci darah ini berfungsi menyaring racun-racun dalam tubuh dan mengeluarkannya, hal ini biasanya dilakukan kepada penderita gagal ginjal. Cuci darah biasanya dilakukan seminggu 2-3 kali. ${ }^{6}$

Trend tindakan HD saat ini meningkat, karena tindakan tersebut merupakan salah satu alternatif yang digunakan oleh pasien gagal ginjal. Jumlah pasien cuci darah (hemodialisis) di Kalimantan Barat cenderung meningkat. Setiap tahunnya, RSUD Soedarso Pontianak harus melayani perawatan terhadap 83 pasien cuci darah. Jumlah ini tergolong tinggi karena diatas angka nasional. Angka nasional sebesar 100 ribu penduduk hanya satu penderita setiap tahunnya. Di Indonesia terdapat sekitar 50.000 pasien gagal ginjal yang harus menjalani cuci darah dan hanya 4.000 orang yang bisa menikmati layanan tersebut, itupun 3.000 orang diantaranya merupakan peserta asuransi kesehatan. ${ }^{7}$

Rumah Sakit Umum PKU Muhammadiyah Unit I adalah salah satu rumah sakit swasta di Yogyakarta. Merupakan rumah sakit terakreditasi 12 bidang pelayanan dengan tipe $C$ plus. Dibawah ini adalah tabel beberapa jenis pelayanan yang terdiri dari beberapa poliklinik spesialis dan sub spesialis yang ditawarkan oleh rumah sakit umum PKU Muhammadiyah Unit I Yogyakarta. 
Tabel 1. Pelayanan yang Ditawarkan RSU PKU Muhammadiyah Yogyakarta Unit I

\begin{tabular}{lll}
\hline No. & Pelayanan & Jumlah \\
\hline 1. & Pelayanan Rawat Jalan. & 14 Poli Spesialis dan Sub Spesialis. \\
\hline 2. & Pelayanan Rawat Inap. & 15 Ruang Waktu. \\
\hline 3. & Unit Penunjang Pelayanan Medis. & 11 Unit. \\
\hline 4. & Unit Penunjang Lainnya dan Unit Non Medis. & 14 Unit. \\
\hline
\end{tabular}

Sumber : Kepegawaian RSU PKU Muhammadiyah Yogyakarta Unit I Tahun 2008

Salah satu unit penunjang pelayanan medis di Rumah Sakit Umum PKU Muhammadiyah Unit I Yogyakarta yang banyak dikunjungi oleh customer adalah instalasi hemodialisis. Berdasarkan data yang diperoleh dari instalasi hemodialisis, jumlah pasien HD pada tahun 2007 sebanyak 13.162 orang dan pada tahun 2008 terdapat 17.006 pasien yang menjalani pengobatan di instalasi hemodialisis.

Hal tarif, instalasi hemodialisis mengeluarkan sebuah program yaitu paket Hemodialisis masyarakat miskin atau biasa disebut dengan paket HD Maskin. Adanya paket tersebut setidaknya dapat memberikan keringanan bagi mereka masyarakat miskin. Kepala bagian hemodialisis menyatakan bahwa, program Askeskin dimulai pada tahun 2003 dan awal beroperasi dengan hanya memiliki 2 mesin HD saja. Kemudian lambat laun mulai ada penambahan mesin dan sekarang Rumah Sakit Umum PKU Muhammadiyah Unit I Yogyakarta telah memiliki 24 mesin HD sedang di Rumah Sakit Umum PKU Muhammadiyah Unit II Yogyakarta telah memiliki 15 mesin HD. Pada tahun 2008 rumah sakit umum PKU Muhammadiyah Unit I Yogyakarta merupakan salah satu rumah sakit terbaik dalam memberikan pelayanan hemodialisis, yang mana juga pernah dimuat dalam koran Kedaulatan Rakyat Yogyakarta.

Penyakit gagal ginjal ini tidak hanya dialami oleh masyarakat kelas menengah keatas, tetapi juga dialami oleh masyarakat kelas menengah ke bawah. Seperti yang kita ketahui bersama bahwa biaya yang harus dikeluarkan untuk bisa melakukan cuci darah tidaklah sedikit. Bahkan, tindakan medis tersebut harus dilakukan secara rutin setiap minggu bagi pasien gagal ginjal kronik. Oleh karena itu, cost sharing sangat diperlukan disini untuk meringankan beban pasien maskin dalam hal tarif hemodialisis. Berdasarkan hasil wawancara dengan kepala bagian di unit hemodialisis menyatakan bahwa, sebesar $60 \%$ pasien HD yang berobat di RSU PKU Muhammadiyah Unit I Yogyakarta adalah maskin. Melihat kenyataan seperti itu, unit hemodialisis mulai menerima pasien Askeskin, yang mana pembiayaannya dibantu oleh pemerintah.

Rumah Sakit PKU Muhammadiyah Unit I Yogyakarta sebelumnya telah menghitung sendiri tarif untuk pasien HD. Tarif HD dibagi menjadi dua yaitu: single use dan re use. Single use sebesar Rp.635.000 sedang untuk re use sebesar Rp.575.000, sedangkan yang diberikan oleh pemerintah untuk pasien Askeskin adalah sebesar Rp.528.067. Diantara tarif HD yang berasal dari rumah sakit dan pemerintah terdapat selisih cost sharing. Peneliti dalam hal ini hanya menghitung tarif HD untuk re use saja, agar nilai cost sharingnya kecil. Selama ini pihak rumah sakit tidak pernah menghitung selisih yang ada. Hal ini dapat menyebabkan rumah sakit jadi merugi, dengan demikian diperlukan penelitian lebih lanjut mengenai topik permasalahan di atas.

\section{METODE PENELITIAN}

Jenis penelitian yang digunakan adalah deskriptif dengan pendekatan kualitatif. Penelitian deskriptif dengan tujuan untuk menggambarkan atau mendeskripsikan 
mengenai tarif yang sesungguhnya terkait dengan tindakan HD maskin di RSU PKU Muhammadiyah Unit I Yogyakarta dengan menggunakan metode real cost.

Alat atau instrumen yang digunakan dalam penelitian ini berupa pedoman wawancara yang dibuat sendiri oleh peneliti, sesuai dengan keperluan peneliti berdasarkan konsep dan teori. Subyek dalam penelitian ini adalah Kepala Bagian Keuangan, dan Kepala Bagian Unit Hemodialisa.

\section{HASIL PENELITIAN DAN PEMBAHASAN}

\section{A. Hasil Penelitian}

\section{1) Pendapat Subyek Penelitian}

Subyek penelitian ini adalah Kepala Bagian Keuangan dan Kepala Bagian Unit Hemodialisis di RSU PKU Muhammadiyah Unit I Yogyakarta. Masingmasing subyek penelitian diberi kesempatan untuk mengemukakan pendapatnya sesuai dengan pedoman wawancara yang telah disediakan.

Pelayanan yang diberikan oleh RSU PKU Muhammadiyah Unit I Yogyakarta di bagian instalasi Hemodialisis pada setiap pasien baik pasien maskin dan pasien biasa diperlakukan atau dilayani dengan sama. Hal ini terungkap berdasar pada wawancara dengan Kepala Bagian Hemodialisis:

“...di Rumah Sakit ini setiap pelayanan yang kami berikan sama saja untuk setiap pasien, kami tidak membeda-bedakan antara pasien Maskin dengan pasien biasa...."

Mengenai sistem perhitungan yang diterapkan di RSU PKU Muhammadiyah Unit I Yogyakarta untuk bagian Hemodialisis adalah berdasarkan pada bahan habis pakai dan dari biaya tenaga kerjanya. Hal ini terungkap dari hasil wawancara pendahuluan dengan Kepala Bagian Keuangan RSU PKU Muhammadiyah Unit I Yogyakarta :

“....Bahwa sistem perhitungan yang kami gunakan untuk menghitung tarif di unit Hemodialisis adalah berdasar pada bahan habis pakai dan biaya tenaga kerja, Rumah Sakit menetapkan tarif sebesar Rp.575.000....".

Perlakuan cost sharing di unit Hemodialisis adalah bahwa selisih yang ada antara tarif rumah sakit dengan tarif pemerintah ditanggung oleh rumah sakit, pasien tidak boleh dikenakan biaya karena akan bertentangan dengan UU Jamkesmas yang ada. Walaupun rumah sakit akan merugi akan hal ini.

\section{2) Jumlah Pasien}

RSU PKU Muhammadiyah Unit I Yogyakarta merupakan salah satu rumah sakit swasta yang memiliki jasa medis Hemodialisa, untuk 1 tempat tidur ada 23 pasien yang menempatinya. Pasien hemodialisis juga dilayani pada sore hari, unit hemodialisis rata-rata menerima pasien hemodialisis pada pagi hari ada 22 pasien, siang hari ada 22 pasien, sedang pada sore hari ada 10-12 pasien. Peningkatan pasien dari tahun ke tahun mengalami kenaikan yang signifikan yaitu pada tahun 2007 terdapat 13.162 orang pasien dan pada tahun 2008 terdapat 17.006 pasien. Hal ini cukup membuktikan bahwa RSU PKU Mhammadiyah Unit I Yogyakarta mendapat kepercayaan dari konsumen khususnya di unit Hemodialisa. Pada tahun 2009 dari bulan Januari sampai Juni terdapat 7.583 pasien yang datang untuk memanfaatkan jasa medis Hemodialisa di RSU PKU Muhammadiyah Unit I Yogyakarta. 


\section{Tahapan-Tahapan Aktivitas dalam Hemodialisis}

Sebelum pasien melakukan Hemodialisa $(\mathrm{Hd})$, pasien $\mathrm{Hd}$ terlebih dahulu melakukan pemeriksaan di laboratorium untuk mengetahui kadar ureum, kreatinin, $\mathrm{Hb}, \mathrm{HbSAg}$ pasien setelah itu pasien melakukan penimbangan berat badan. Setelah itu, pasien melakukan hemodialisa. Melakukan hemodialisa terdapat beberapa aktivitas atau tahapan yang harus dilakukan, yakni :

a) Rinsing ; membilas mesin dengan cairan disinfektan dan air didalam sirkulasi mesin,

b) Setting ; memasang selang/cateter pada infus,

c) Premming ; mengisi $\mathrm{NaCl}$ ke saluran ekstral corporeal, Soaking; menyambung dialiser dengan dialisat,

d) Aksesing ; melakukan akses vaskuler/menyuntik pasien,

e) Programming ; memprogram mesin,

f) Procecing; proses dialisa,

g) Ending; mengakhiri Hd,

h) Rinsing ; membilas mesin dengan cairan disinfektan dan air didalam sirkulasi mesin.

\section{Biaya Bahan Habis Pakai}

Tabel 3. Rincian Biaya Penggunaan Bahan Habis Pakai di Instalasi Farmasi RSU PKU Yogyakarta 2009

\begin{tabular}{|c|c|c|c|}
\hline No. & Bahan Habis Pakai & Jumlah BHP & Harga \\
\hline 1. & Kassa DRC & $40 \mathrm{CM} \times 80 \mathrm{CM}$ & 123.701 \\
\hline 2. & Spuit $10 \mathrm{cc}$ & 1 & 3.355 \\
\hline 3. & Spuit 3 cc & 1 & 2.083 \\
\hline 4. & Spuit $1 \mathrm{cc}$ & 1 & 5.544 \\
\hline 5. & Tranfusi Set & 1 & 29.106 \\
\hline 6. & Lidocain AMP & 1 & 1.247 \\
\hline 7. & Alkohol & $5 \mathrm{cc}$ & 175 \\
\hline 8. & Perhidrol & $15 \mathrm{cc}$ & 13.155 \\
\hline 9. & Hemoclin & $10 \mathrm{cc}$ & 3.880 \\
\hline 10. & $\mathrm{NaCl} 500 \mathrm{ml}$ & 3 flabot infus & 16.632 \\
\hline 11. & AVBL & 1 & 77.616 \\
\hline 12. & AV Fistula & 2 & 26.334 \\
\hline \multirow[t]{2}{*}{13.} & Hollow Fiber & $1 \times$ (hf baru) & 156.724 \\
\hline & Jumlah & & 459.552 \\
\hline
\end{tabular}

Sumber : Instalasi Farmasi RSU PKU Muhammadiyah Unit I Yogyakarta 2009

\section{5) Analisis Biaya}

Mengidentifikasikan kegiatan yang ada di unit Hemodialisa yang terdiri dari biaya langsung dan tidak langsung. Data yang diperoleh adalah data pada tahun 2009, yaitu dari bulan Januari sampai bulan Juni yang mana merupakan trimester I, karena RSU PKU Muhammadiyah Unit I Yogyakarta menggunakan 
dua trimester. Trimester I jatuh pada bulan Januari sampai bulan Juni, lalu trimester II jatuh pada bulan Juli sampai bulan Desember.

\section{a) Biaya Langsung}

Biaya langsung adalah suatu kegiatan yang menghasilkan biaya dan berhubungan langsung dengan pasien, yaitu :

Biaya Laboratorium sebesar

Rp. 118.500

Biaya Bahan Habis Pakai sebesar

Biaya Tenaga Kerja sebesar

Rp. 459.552

Biaya Dokter sebesar

Rp. 232.312

Biaya pendaftaran sebesar

Rp. 70.000

Rp. $\quad 7.500$

\section{b) Biaya Tidak Langsung}

Biaya tidak langsung adalah biaya yang terjadinya tidak berhubungan langsung dengan pasien, yaitu terdiri dari biaya depresiasi alat medik dan non medik, biaya gedung, biaya pemeliharaan, biaya listrik, biaya kebersihan, biaya pengadaan barang, dan biaya linen dan laundry.

1) Biaya Listrik

Biaya total listrik di RSU PKU Muhammadiyah Unit I Yogyakarta pada tahun 2009, selama 6 bulan adalah sebesar Rp. 9.257.430 dimana masing-masing pasien dikenakan biaya dengan perhitungan:

$$
\begin{aligned}
& =\frac{\text { Total listrik selama } 6 \text { bulan }}{\text { Jumlah pasien selama } 6 \text { bulan }} \\
& =\frac{\text { Rp. } 9.257 .430}{7.583} \\
& =\text { Rp. } 1.220
\end{aligned}
$$

2) Biaya Depresiasi

a) Depresiasi Bangunan

Merupakan biaya penyusutan dari bangunan di unit Hemodialisa selam 6 bulan yaitu sebesar Rp.50.000.000 dan masing-masing pasien dikenakan biaya dengan perhitungan :

$$
\begin{aligned}
& =\frac{\text { Jumlah biay a bangunan selama } 6 \text { bulan }}{\text { Jumlah pasien selama } 6 \text { bulan }} \\
& =\frac{\text { Rp. } .50 .000 .000}{7.583} \\
& =\text { Rp. } 6.593
\end{aligned}
$$

b) Depresiasi Alat Medis dan Non Medis

Merupakan penyusutan alat medis dan non medis, yaitu sebesar Rp.31.513.166 dan masing-masing pasien dikenakan biaya dengan perhitungan : 
$=\frac{\text { Total penyusutanalat medis dan non medis selama } 6 \text { bulan }}{\text { Jumlah pasien selama } 6 \text { bulan }}$

$=\frac{\operatorname{Rp} \cdot 31.513 .166}{7.583}$

$=$ Rp. 4.155

c) Biaya Pemeliharaan

Biaya pemeliharaan di RSU PKU Muhammadiyah Unit I Yogyakarta selama 6 bulan adalah sebesar Rp. 5.698.500, yang mana masing-masing pasien dikenakan biaya dengan perhitungan :

$=\frac{\text { Jumlah biaya pemeliharaan selama } 6 \text { bulan }}{\text { Jumlah pasien selama } 6 \text { bulan }}$

$=\frac{R p \cdot 5 \cdot 698.500}{7.583}$

$=\operatorname{Rp} .751$

d) Biaya Kebersihan

Biaya kebersihan di RSU PKU Muhammadiyah Unit I Yogyakarta selama 6 bulan adalah sebesar Rp. 9.000.000, yang mana masingmasing pasien dikenakan biaya dengan perhitungan :

$=\frac{\text { Jumlah biaya kebersihan selama } 6 \text { bulan }}{\text { Jumlah pasien selama } 6 \text { bulan }}$

$=\frac{\text { Rp.9.000.000 }}{7.583}$

$=$ Rp. 1.186

e) Biaya Pengadaan Barang

Biaya pengadaan barang di unit Hd di RSU PKU Muhammadiyah Unit I Yogyakarta selama 6 bulan adalah sebesar Rp. 45.365.472, yang mana masing-masing pasien dikenakan biaya dengan perhitungan :

$=\frac{\text { Jumlah biay a pengadaan barang selama } 6 \text { bulan }}{\text { Jumlah pasien selama } 6 \text { bulan }}$

$=\frac{\operatorname{Rp} \cdot 45 \cdot 365.472}{7.583}$

$=$ Rp. 5.982

$\begin{array}{ll}\text { f) Biaya Linen dan Laundry } & \text { Rp. } 5.000\end{array}$

\section{c) Biaya Total}

Biaya total adalah biaya yang dikeluarkan oleh unit Hemodialisa di RSU PKU Muhammadiyah Unit I Yogyakarta pada tahun 2009 yang terdiri dari biaya langsung dan biaya tidak langsung. Berdasarkan hasil identifikasi dan 
analisi terhadap biaya langsung dan tidak langsung, dapat diketahui biaya total untuk tindakan Hemodialisa maskin yang digunakan oleh RSU PKU Muhammadiyah Unit I Yogyakarta, yaitu :

Biaya Laboratorium
Biaya Bahan Habis Pakai
Biaya Tenaga Kerja
Biaya Dokter
Pendaftaran
Biaya Listrik
Depresiasi Bangunan
Biaya Pemeliharaan
Depresiasi Alat Medis dan Non Medis
Biaya Kebersihan
Biaya Pengadaan Barang
Biaya Linen dan Laundry

Jumlah

$\begin{array}{lr}\text { Rp. } & 118.500 \\ \text { Rp. } & 459.552 \\ \text { Rp. } 232.312 \\ \text { Rp. } & 70.000 \\ \text { Rp. } & 7.500 \\ \text { Rp. } & 1.220 \\ \text { Rp. } & 6.593 \\ \text { Rp. } & 751 \\ \text { Rp. } & 4.155 \\ \text { Rp. } & 1.186 \\ \text { Rp. } & 5.982 \\ \text { Rp. } & 5.000 \\ \text { Rp. } & 912.751\end{array}$

\section{B. PEMBAHASAN}

\section{1) Selisih Tarif yang Ada}

Berdasarkan penelitian ini dapat diketahui bahwa tarif yang dikenakan oleh pihak RSU PKU Muhammadiyah Unit I Yogyakarta adalah sebesar Rp. 575.000. Penentuan tarif untuk tindakan Hemodialisa ini adalah menggunakan metode real cost. Secara umum hasil analisis metode real cost adalah digunakan untuk penentuan harga pokok produk/jasa, pengendalian biaya (berhubungan dengan anggaran), pengambilan keputusan, dan mengidentifikasi sistem akuntansi biaya. ${ }^{8}$

Tabel 4. Selisih Antara Tarif Rumah Sakit untuk Hd Maskin dan Perhitungan Tarif Hd Maskin Menggunakan Metode real cost.

\begin{tabular}{llll}
\hline & $\begin{array}{l}\text { Tarif yang berlaku } \\
\text { dari pihak rumah sakit } \\
\text { dan Jamkesmas }\end{array}$ & $\begin{array}{l}\text { Tarif Hd Maskin di } \\
\text { RSU PKU } \\
\text { Muhammadiyah } \\
\text { Yogyakarta. } \\
\text { Menggunakan } \\
\text { Metode real cost }\end{array}$ & $\begin{array}{l}\text { Selisih Antara Tarif Hd } \\
\text { Maskin dengan } \\
\text { menggunakan metode } \\
\text { real cost }\end{array}$ \\
\hline Rumah Sakit & Rp.575.000 & Rp. 912.751 & Rp. 337.751 \\
\hline Jamkesmas & Rp.528.067 & Rp. 912.751 & Rp.384.684 \\
\hline
\end{tabular}

Berdasarkan tabel di atas bahwa tarif yang diberikan oleh RSU PKU Muhammadiyah Unit I Yogyakarta adalah sebesar Rp. 575.000 sedangkan tarif yang menggunakan metode real cost lebih tinggi yaitu sebesar Rp. 912.751 dan selisih diantara kedua tarif tersebut adalah sebesar Rp. 337.751 . Sedangkan tarif yang diberikan oleh pemerintah atau Jamkesmas adalah sebesar Rp. 528.067 dan selisih antara kedua tarif tersebut adalah sebesar Rp.384.684. Berdasarkan data diatas dapat dikatakan bahwa rumah sakit mengalami kerugian karena harus membayar selisih dari kedua tarif tersebut. Tarif dapat berada di bawah, sama, atau diatas unit cost. Apabila tarif berada dibawah unit cost berarti rumah sakit mengalami kerugian. ${ }^{9}$ 
Hemodialisis merupakan salah satu dari PPE (Paket Pelayanan Esesensial) Jamkesmas. Namun, rumah sakit masih memiliki paket pelayanan lainnya terkait dengan Jamkesmas seperti CT. Scan, tindakan operasi caecar dan lainlainnya, sehingga Rumah Sakit PKU Muhammadiyah Yogyakarta masih bisa bangkit dari kerugian yang ada karena mendapat subsidi dari pelayanan kesehatan lainnya. Paket pelayanan esensial merupakat sistem paket, dimana sistem paket tersebut memiliki sisi negatif dan positifnya, dimana bila dari segi negatif bahwa rumah sakit harus bisa menekan biaya produksi untuk bisa bekerjasama dengan pihak Jamkesmas. Sisi positifnya dapat dilihat dari terjadi peningkatan captive market, berkurangnya bad debt (piutang ragu-ragu), terkait dengan visi misi Rumah Sakit PKU Muhammadiyah tentang kaum dhuafa, terdapat anggaran untuk dana sosial terkait dengan Jamkesmas.

Standar costing tersebut salah satunya adalah menggunakan metode real cost yang mana metode tersebut terdiri dari tiga komponen; yaitu bahan habis pakai, biaya tenaga kerja, dan biaya overhead. Ketiga komponen tersebut merupakan unit cost atau harga pokok penjualan, dari komponen tersebut rumah sakit menetapkan harga pokok penjualannya. Namun, yang terjadi di Rumah Sakit PKU Muhammadiyah Yogyakarta, hanya menghitung dari sisi biaya bahan habis pakai dan biaya tenaga kerja saja, biaya overhead tidak dihitung sehingga tarif yang diberikan oleh rumah sakit rendah. Oleh karena itu, dibutuhkan data informasih yang akurat, sehingga pihak rumah sakit tidak dirugikan.

\section{2) Struktur-Struktur Biaya yang Bisa Diefisiensikan}

a) Biaya Bahan Habis Pakai

\begin{tabular}{llll}
\hline No. & \multicolumn{1}{c}{ Bahan Habis Pakai } & \multicolumn{1}{c}{ Jumlah BHP } & Harga \\
\hline 1. & Kassa DRC & $40 \mathrm{CM} \mathrm{X} \mathrm{80} \mathrm{CM}$ & 123.701 \\
\hline 2. & Spuit $10 \mathrm{cc}$ & 1 & 3.355 \\
\hline 3. & Spuit 3 cc & 1 & 2.083 \\
\hline 4. & Spuit 1 cc & 1 & 5.544 \\
\hline 5. & Tranfusi Set & 1 & 29.106 \\
\hline 6. & Lidocain AMP & 1 & 1.247 \\
\hline 7. & Alkohol & $5 \mathrm{cc}$ & 175 \\
\hline 8. & Perhidrol & $15 \mathrm{cc}$ & 13.155 \\
\hline 9. & Hemoclin & $10 \mathrm{cc}$ & 3.880 \\
\hline 10. & NaCl $500 \mathrm{ml}$ & $3 \mathrm{flabot}$ infus & 16.632 \\
\hline 11. & AVBL & 1 & 77.616 \\
\hline 12. & AV Fistula & 2 & 26.334 \\
\hline 13. & Hollow Fiber & $1 / 5 \times$ (hf baru) & 31.344 \\
\hline & Jumlah & & 334.172 \\
\hline
\end{tabular}


Hollow fiber yaitu suatu alat untuk memproses dalam hal pembersihan darah di luar tubuh pasien dan bisa diefisien kan yaitu dengan satu hollow fiber bisa digunakan untuk lima orang pasien, sehingga harganya bisa diefisienkan dari Rp.156.724 menjadi Rp.31.344.

b) Biaya Dokter

Biaya dokter bisa diefiesienkan dari Rp. 70.000 menjadi Rp. 35.000. Berdasarkan ketentuan yanga dibuat oleh pihak rumah sakit yaitu dipotong sebesar $50 \%$ dalam hal penanganan masyarakat miskin, serta harus bedasarkan kesepakatan bersama antara rumah sakit dengan dokter, karena terkait dengan visi misi rumah sakit tentang kaum dhuafa.

c) Biaya Tenaga Kerja

Biaya tenaga kerja yang semula Rp. 232.312 bisa diambil dari gaji pokoknya saja karena gaji pokok tersebut bersifat tetap atau berdasarkan hari kerja petugas, sehingga bila dihitung dengan depresiasi menjadi Rp. 65.734 yang dibayar oleh pihak rumah sakit. Tanpa harus ada tunjangan yang lainnya.

d) Biaya Linen dan Laundry

Biaya linen dan laundry yang semula Rp.5000 bisa diefisienkan menjadi Rp.2.500 karena hanya sprei dan sarung bantal saja yang menjadi beban biayanya.

\section{3) Biaya-Biaya dan Aktifitas-Aktifitas yang Bisa Di Elemenier}

a) Biaya Laboratorium

Pasien Hd melakukan pemerikasaan laboratorium untuk mengetahui kadar ureum, keatinin, $\mathrm{Hb}$, dan $\mathrm{HbSag}$. Pemeriksaan laboratorium tidak selalu dilakukan kepada setiap pasien, karena pasien juga terlebih dahulu melakukan ckeck up sebelumnya. oleh karena itu bisa meringankan beban rumah sakit dalam hal pembiayaan laboratorium.

b) Biaya Pendaftaran lainnya.

Biaya tersebut bisa ditiadakan karena bisa di subsidi silang dari unit

Diharapkan pihak rumah sakit dapat menghitung kembali tarif yang ada, yang mungkin tidak memerlukan watu yang lama untuk melakukannya, karena Rumah Sakit PKU Muhammadiyah Yogyakarta juga menggunakan metode real cost dalam perhitungan tarifnya, hanya perhitungan komponen biaya overheadnya saja yang di tambah dalam melakukan evaluasi perhitungan tarif yang ada.

\section{SIMPULAN DAN SARAN}

\section{A. Simpulan}

1) Berdasarkan perhitungan dengan menggunakan metode real cost, maka diperoleh unit cost sebesar Rp. 912.751 sedangkan tarif yang diberikan oleh rumah sakit adalah sebesar Rp. 575.000. Terdapat selisih antara tarif rumah

KES MAS Vol. 5, No. 3, September 2011: 162-232 
sakit dengan unit cost yaitu sebesar Rp.337.751. tarif yang diberikan oleh pemerintah sebesar Rp. 528.067 dan selisihnya dengan unit cost adalah Rp. 384.684 .

2) Biaya-biaya yang bisa di efisienkan adalah biaya bahan habis pakai menjadi Rp. 334.172; biaya tenaga kerja menjadi Rp. 65.734; biaya dokter menjadi Rp. 35.000; biaya linen dan laundry menjadi Rp. 2.500.

3) Biaya-biaya dan aktifitas-aktifitas yang bisa di elimeneir, yaitu biaya laboratorium yang mana tidak semua pasien harus melakukan pemeriksaan laboratorium; biaya pendaftaran dapat dihilangkan karena bisa mendapatkan subsidi dari unit lainnya.

\section{B. Saran}

1) Bagi RSU PKU Muhammadiyah Unit I Yogyakarta

a) Mengetahui selisih yang harus ditanggung pasien terhadap tarif yang sesungguhnya. Serta pihak rumah sakit perlu mengevaluasi kembali tarif yang ada, demi kelangsungan hidup rumah sakit.

b) Mengetahui struktur-struktur biaya apa saja yang bisa diefisiensikan.

c) Mengetahui biaya-biaya dan aktifitas-aktifitas yang bisa dielimenier terkait dengan cost sharing di RSU PKU Muhammadiyah Unit I Yogyakarta.

2) Peneliti Lain

Bagi peneliti selanjutnya diharapkan untuk dapat lebih mendalam penelitian melalui suatu penelitian dari segi finansialnya, yaitu tentang besarnya kerugian yang telah dialami pihak rumah sakit sejak melakukan kerjasama dengan pihak Jamkesmas.

\section{DAFTAR PUSTAKA}

1. Chusnun, S.P., Efisiensi Layanan Kesehatan: http://www.pamjaki.org diambil pada tanggal 15 Juli 2009, Yogyakarta. 2009

2. Patriajati, Sutopo, Nambah Ilmu Tentang Konsep luran Biaya dalam Askes: http:// www.scribd.com diambil pada tanggal 15 Juli 2009, Yogyakarta. 2009

3. Sugiarto, A., Julita Hendrartini., Ali Gufron Mukti, "Persepsi Stakeholder Terhadap Perubahan Pola Kontrak Kapitasi Total Biaya Pelayanan Kesehatan Peserta Wajib PT.Askes dari Basis Kabupaten ke Basis Puskesmas di Kabupaten Kuloprogo", Jurnal Manajemen Pelayanan Kesehatan, Volume 06/ No.04/2003. 2009

4. Bonasir, Rohmatin, Laporan Khusus Problematika Kemiskinan di Indonesia: http:// www.bbc.co.uk diambil pada tanggal 28 Mei 2009, Yogyakarta. 2009

5. Rakyat Merdeka, Angka Harapan Hidup Orang Indonesia 67,8 Tahun: http:// www.rmexpose.com_diambil pada tanggal 28 Mei 2009, Yogyakarta. 2007

6. Bio mineral, Cuci Darah-Hemodialisa: http://bio-mineral.com, diambil pada tanggal 4 April 2009, Yogyakarta. 2008

7. Pontianak Post, Pasien Cuci Darah Di Kalbar Meningkat Tajam: http:// arsip.pontianakpost.com_diambil pada tanggal 14 Mei 2009, Yogyakarta. 2009

8. Raymond, T., Perhitungan Unit Cost untuk Orang Miskin di Rumah Sakit, Pusat Manajemen Pelayanan Kesehatan FK-UGM, Yogyakarta. 2001

9. Trisnantoro, L., Memahami Penggunaan Ilmu Ekonomi dalam Manajemen Rumah Sakit, Gajah Mada University Press, Yogyakarta. 2006 